\title{
The biblical ethics of WORK: A MODEl for African nations
}

Author:

Godwin N. Toryough ${ }^{1}$

Affiliation:

${ }^{1}$ Department of Religious

Studies, University of

Ibadan, Nigeria

Correspondence to:

Godwin Toryough

email:

revtoryough@yahoo.co.uk

Postal address:

Department of Religious

Studies, University of

Ibadan, Ibadan, Oyo State,

Nigeria

\section{Keywords:}

work ethics; Nigeria;

concept of work; African

Nations; employer-

employee relationship

\section{Dates:}

Received: 08 Dec. 2009

Accepted: 14 Oct. 2010

Published: 23 Nov. 2010

How to cite this article: Toryough, G.N., 2010, 'The biblical ethics of work: A model for African nations', Verbum et Ecclesia 31(1), Art \#363, 8 pages. DOI: 10.4102 / ve.v31i1.363

\section{This article is available}

http://www.ve.org.za
(C) 2010. The Authors.

Licensee: OpenJournals Publishing. This work

is licensed under the

Creative Commons

Attribution License.

\section{ABSTRACT}

This article has unpacked issues surrounding workers' poor attitude in terms of work and focuses on Nigeria and on Africa at large. It addresses the lapses of labour for both employers and the employees, which include misconduct, non-commitment, unfaithfulness, apathy and exploitation, amongst other things. It is the argument of this article that a misconception of work and a lack of work ethics are some of the major factors responsible for these negative attitudes. In order to get around this perceived problem, the article suggests a theological solution which is rooted in the Christian Scriptures. Thus polemic approaches as well as an exegesis of the Scriptures concerning the right concept and attitude to work are employed in this study. The synchronic approach to exegesis is employed in this work. This approach looks at the final form of the text as it stands in the Bible. The particular components of this approach applied in this article are narrative and rhetorical criticism whilst others involve lexical, grammatical and syntactical analysis. In addition, the Intercultural Hermeneutics approach of contextualization is employed. The article points out how work which, from a theological perspective, originated with creation and was not intended to be evil later became conceived as a kind of punishment. It also demonstrates how work became bifurcated into secular and spiritual spheres with its attendant negative consequences in the Middle Ages. It concludes with a presentation of the biblical ethics of work which is recommended as a benchmark for attitudinal change in stakeholders.

\section{INTRODUCTION}

The attitude to work exhibited by workers of the public and private sectors in Nigeria in particular (and in many other African countries) is not commendable. There is gross misconduct, non-commitment, unfaithfulness, dishonesty, stealing of both time and resources and a general apathy on the part of employees. On the part of management or the employers of labour, exploitation of the employees and a great apathy towards the welfare conditions of employees thrive. All these factors come together to midwife the inefficiency and the poor results being witnessed in industries in the continent (Dzurgba 2003:46). The consequences of this are the slow pace of technological development, the substandard quality of services and consumer products and the poverty level of Africans in spite of the huge natural and manpower resources in the continent. This type of attitude prompted Governor Martin Elechi of Ebonyi state, one of the states of Nigeria, to convene a public discourse titled Ebonyi Gathering for Attitudinal Change (1) in order to halt this ugly trend (Uka 2010).

One does not need to dig deep to discover that one of the things responsible for this abysmal state of the labour industry in Africa is our concept of work or lack of work ethics. This is because individuals' notion of work would determine how much time and energy they devote to it. It is in the light of this that we seek in this article to present the biblical perspective of work ethics with a view on helping the countries of Africa to achieve their dream of becoming world-class economies in the 21st century.

Our approach would be to establish the biblical view of work, to present the biblical ethics of work and demonstrate how an application of the biblical ethics of work could be of invaluable benefit to the nations of Africa. In doing this the synchronic method of exegesis is employed. Also to a lesser degree the article applies the existential method of exegesis in trying to proffer solution to this major developmental problem of Nigeria and Africa at large.

\section{THE BIBLICAL PERSPECTIVE OF WORK}

Our opinion of work is conditioned by our experience of work but is also, to a large extent, based on our notion of the origins of work. Many people of the world, religious and non-religious alike have various ideas about the origins of work. This has given rise to different concepts of work.

To the naturalist or freethinker, work evolved as humankind struggled to master their environment and in a bid to have their needs met in order to survive in the world. This view identifies Homo sapiens as a hunter and farmer (gatherer of fruits) at the initial stage of their development and argues that with the passage of time, human beings developed skills in various areas, resulting in the diversification of work. This notion of the origin of work conceives it as being necessary only for human beings' survival (Natural Theology Synopsis 2007).

However, to the people of the Book, God created work. There is, however, disagreement amongst them over how, when and why God introduced work to human beings. Some hold that work came only after the fall of Adam and Eve and was introduced only as penalty for their rebellion against God. If this view was endorsed, work would be seen as an evil rather than a good to humanity. It is in the light of the foregoing that Matt Harmon (2007) writes that in the United States of America, many people regard work as something to be avoided and endured until the next opportunity for recreation. Others, however, hold that work was introduced before the fall and is not to be seen as an evil to contend with consequent on human beings' fall and rebellion against God. In the light of this complicity, what does the Bible teach about the origins of work? 


\section{The Bible on the origins of work}

The question of how work originated takes us back to the book of Genesis, which is the Bible book of origins. This book has much information about the origin of work. The very first verse of the book (Gn 1:1) reports that in the beginning, God created the heavens and the earth. This is followed by the report that God took the next six days and furnished all the heavens and the earth with all their hosts. At the end of these creation activities, God rested on the seventh day from His work (Gn 2:2). In whatever way we choose to understand these six days of creation, whether in a literal or literary way or in terms of progressive epochs or otherwise, all Bible-believing Christians agree that creation is the handiwork of God. The logical and obvious conclusion arising from this, therefore, is that work originated with God himself. God is a working God. This fact alone puts to an end the notion that work is evil. If God himself works, then work must be something dignifying.

Closely related to the foregoing is the fact that God as a working God, created human beings in his image and likeness (Gn 1:26, 27). H.H. Davis (1988:728) recognises this when he writes that the character of work is shaped, first by the fact that human beings are made in God's likeness with the capacity to participate actively in the wider creation. What this means is that as creatures made in God's image and likeness, we take after him in this attribute of being a worker.

It is in trying to make us conform to that image of God (i.e. of a working being), that God categorically charged human beings at the very beginning with the responsibility of working in the Garden of Eden (Gn 2:15). Adam and Eve were instructed to till and keep the garden. Robert S. Rayburn (2006) asserts, in line with this, that, 'the very first command ever given to humans, indeed the very first word spoken to them, was a command to work, to perform a particular job'. This is no exaggeration at all, as in both accounts of creation in Genesis God's first word to humans has to do with work of some kind. In Genesis 1:28, humans are commanded to be fruitful, multiply and fill the earth and subdue it and have dominion over the fish of the sea and over the birds of the air and over every living thing that moves upon the earth (NRSV). This is an enormous task or work, which involves humans in procreation (which is the continuity of the creation of humans on God's behalf) and in serving as God's stewards in the oversight and preservation of the other creatures of God. In Genesis 2:15, as we have already noted, humans are commanded to till and keep the Garden of Eden, which is a command to work (Barker \& Kohlenberger 1994:7). Thus, whichever account of creation one chooses to endorse as authentic and whatever mode of interpretation one adopts for the Genesis cosmology, one cannot evade God's command to work. Work, therefore, is created by God.

It is pertinent to highlight here that the command to work was given to humans before the Fall. This, then, implies that work did not come to humans in consequence of the Fall (Gn 3:1-19). Rather, work is a basic dimension of human existence. Later on, when God gave the Ten Commandments to Israel, he included commandments about work. The commandment about keeping of the Sabbath Day is tacitly, a command about work. Human beings are to work six days in a week and rest for just a day. This rest is actually not leisure per se, for it includes the worship of Yahweh. Similarly, the commandments not to steal and not to covet another person's property are commands to human beings to do their own work and earn a living so that they would not have to steal other people's property. Apart from that, Psalm 104:19-24 and Isaiah 28:23-29 praise God's wisdom in making human beings as workers (McDonald 1982:1260).

In the same vein and in terms of the New Testament, we find that it also teaches that work is of God. Although we may not find specific passages that deal with the subject of the Christian approach to labour in general, we find passages that glorify work (Guthrie 1981:940-41). For instance, Jesus viewed His own ministry as work (see Jn. 4:34 \& 1\&:4). He also identified God as a working God in the statement, 'My Father is still working, and I also am working' (Jn 5:17 NRSV). The incarnation of God as the Carpenter of Nazareth is the perfect fulfillment of the teaching that work is necessary and good (Davis 1988:728). Besides, the New Testament does not draw a distinction between various kinds of work or occupation. As D. Guthrie observes,

there is no suggestion of contempt for manual work as amongst the Greeks. Indeed, both Jesus and Paul were craftsmen, following the established tradition that males should learn a trade, even those destined to become rabbis.

(Guthrie ibid:940)

The foregoing demonstrates that work has its origin in God. It also shows that work of all kinds is dignifying and that just as God himself works, human beings, created in his image and likeness, are created to work.

\section{The double perspective of scripture on work}

Our main focus in the preceding section is on the origins of work. Thus, the conclusions we have drawn converge on the thesis that God originated work and therefore work is good, holy and it is the will of God for humans. Human beings are therefore expected to conceive of work in positive terms. We must, however, point out that, this is just one side of the coin. As a matter of fact, the Scriptures have both positive and negative perspectives of work. This is made clear through the various biblical terms used in the Old and New Testaments to denote work either as a positive or negative enterprise.

For the positive terms, we have ma'aseh in the Old Testament and eprov (ergon) in the New Testament. All of these words are neutral just as the English word 'work'. They denote 'work', 'employment' and 'task'. Primarily, they refer to work that is easy and pleasant or enjoyable (Vine \& Unger 1996). This nuance would correspond to work as God intended it at the beginning of the universe.

Negatively, there are Hebrew and Greek terms employed by the Bible to denote work, which are translated as 'toil' or 'labour', implying that work is wearying, troublesome and unfulfilling.

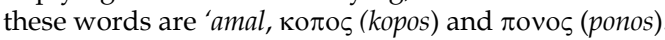

The Old Testament word 'amal means 'labour', 'toil', 'anguish', 'troublesome work', 'trouble' and 'misery'. It occurs 55 times in later poetic and prophetic literature. Vine's Dictionary identifies the word with the following meanings: firstly, it means 'labour' in the sense of toil (Dt 26:7). Secondly, something gained by toil or labour is 'amal' (Ps 105:44). Thirdly, it refers to 'troublesome' work with a focus on the difficulty involved in a task or work as troublesome and burdensome (Eccl 1:3). Fourthly, the emphasis sometimes shifts to the area of trouble so that an enterprise or situation is exclusively troublesome or unfortunate (Gn 41:51). Lastly, 'amal can have an ethical connotation and is used as a word for sin as in Ps.7:14 (Vine \& Unger 1996:293-95).

Similarly, the New Testament word, kopos primarily denotes 'a striking or beating'. It also means to 'toil' resulting in weariness, laborious toil and trouble and is translated as labour or labours or weariness in various New Testament passages. The other word, ponos, also denotes labour or toil (see Col 4:13 \& Rv 16:10 $\& 11)$.

This notion of work as hardship, trouble or wearying toil, is found throughout the Bible. However, the book of Ecclesiastes brings it out more clearly and forcefully. Thus, when the author says, 'What does man gain from all his labour at which he toils under the sun?' he implies that work is futile, troublesome and wearying. This is re-echoed in Ecclesiastes 2:11, 17-23; 4:4 and $5: 15-16$. This should not be seen as a contradiction of the positive perspective of work. Rather, we should see it as the resulting 
development of human beings' relationship with God. The first three chapters of the book of Genesis give us information about this double perspective of work. In chapters 1 and 2, work is portrayed as originated by God. It is human beings' calling and one of the reasons why they are created by God and it is good and fulfilling. In the third chapter, however, work takes on the toilsome or burdensome dimension owing to the sin of mankind (usually referred to as the Fall of Man). The ground is cursed by God and is to bring forth thorns and thistles for humans. Humans are to eat, henceforth, only through the sweat of their brow arising from burdensome toil (Hargreaves 1998). This does not suggest that work ceases to be good or that it ceases to be God's calling for humans. It is rather that work takes on some added effort.

\section{Rayburn (2006) draws the conclusion that}

the two perspectives of work teach us the doctrine of work drawn from the Creation and the fall and a view of work that is realistic and affirming at the same time.

(Rayburn 2006)

This means that we should not be preoccupied with work to such an extent that it takes the place of God. We should realise that there is something more important than work, something of eternal value, that is, God. We should not worship our work and should not put our trust in it. The only thing that brings true fulfillment is God.

The question that arises naturally from the conclusions of the foregoing is this: If work is originated by God and if it is good and fulfilling, how did Christianity come by its doctrine of work as being a mundane or secular activity, against church ministry as being sacred or spiritual?

Rayburn (2006) informs us that the Early Church conceived work as holy and did not dichotomise between sacred and mundane, secular and spiritual work. Reference is made to the ancient writing of Diognetus, dated about 150 A.D. in which the Bishop shows that the early Christians shared a common life with their counterparts in the world; doing the same kinds of jobs as their neighbours, but with a difference; that they are decidedly and unabashedly followers of Christ in the way they do their work. Thus, they worked out their holiness in the ordinary callings of their lives. The implication of this is that, all ordinary works of 'ordinary' Christians were seen as holy, just as the work of church clerics.

However, in the 4th century A.D., things had changed. The 4th century A.D. Church historian, Eusebius, wrote thus about the Church's notion of work in the 4th century A.D.:

Two ways of life were ... given by the law of Christ to his church. The one above nature, and beyond common human living; it admits not marriage, childbearing, property nor the possession of wealth, but, wholly and permanently separate from the common customary life of mankind, it devotes itself to the service of God alone in its wealth of heavenly love! And they who enter on this course appear to die to the life of mortals, to bear with them nothing earthly but their body, and mind and spirit to have passed to heaven ... Such then is the perfect form of the Christian life. And the other, more humble, more human, permits men to join in pure nuptials and to produce children, to undertake government, to give orders to soldiers ...; it allows them to have minds for farming, for trade, and the other more secular interests as well as for religion; and it is for them that times of retreat and instruction, and days for hearing sacred things are set apart. And a kind of secondary grade of piety is attributed to them, giving just such help as such lives require, so that all men ... have their part in the coming of salvation, and profit by the teaching of the gospel.

(Eusebius n.d. cited by Rayburn 2006)

This demonstrates that by the time of Eusebius the occupations of most Christians came to be looked down upon as being less spiritual or even unspiritual and became tagged as secular or mundane and were indulged in only by those whose spirituality was low and those who could not aspire to spiritual vocations. Thus, the nuns, monks and gospel ministers came to be seen as those who lived the true life on the higher level and worked to serve God, whilst the rest who indulged in mundane or secular work, did so only to eat. The great scholars of this age wrote in derision of secular work. Augustine declared business to be evil, whilst Jerome wrote that, 'a merchant can seldom if ever please God' (Rayburn 2006).

It should not be surprising to us that there was this sudden turn in the concept of work by the Church if we had an insight into the influences that came upon the Church. From the second century A.D. onwards, the teachings of Gnosticism flooded the Church and sandwiched the latter's doctrines. The principal doctrine of Gnosticism was that 'Matter is evil'. Those who were spiritual or who possessed gnosis (knowledge) were to adopt ascetic ways of life to escape evil, which included extreme fasting, abstinence from sexual intercourse, celibacy, taking a vow of perpetual poverty, et cetera (Kuiper 1964:17). Apart from that, the world, being material, was thought to be evil in nature and therefore was a place from which to escape (Boer 1976:55). Similarly, some Jewish rabbis had also maintained that work other than working on the Torah was of no serious consequence; that only the study and teaching of the Torah was important. The following words of a rabbi cited in the Talmud illustrate this:

I thank thee, O Lord, my God, that thou hast given me my lot with those who sit in the house of learning, and not with those who sit at the street corners; for I am early to work and they are early to work; I am early to work on the words of the Torah, and they are early to work on the things of no moment. I weary myself, and they weary themselves; I weary myself and profit thereby, and they weary themselves to no profit. I run, and they run; I run towards the life of the age to come, and they run towards the pit of destruction.

(Jeremias n.d. cited by Rayburn 2006)

It must be pointed out, however, that not all the Jewish rabbis may have thought of work as represented in the preceding quotation. For instance, the sages of the academy in Jabnah in expressing their regard for human beings, learned and unlearned, had this to say which also expresses their notion of work:

I am a creature of God and so is my neighbor. He may prefer to labour in the country; I prefer a calling in the city. I rise early for my personal benefit; he rises early to advance his own interests. As he does not seek to supplant me, I should be careful to do naught to injure his business. Shall I imagine that I am nearer to God because my profession advances the cause of learning and his does not? No. Whether we accomplish much good or little good, the Almighty will reward us in accordance with our righteous intentions.

(Polano 1973:260)

Whilst it is apparent from the two quotations that the rabbis may have contradicted one another over their notion of work one fact remains that at least some of them felt that working as religious clerics was of greater value than otherwise. Thus all these factors must have come together to give the Church this new understanding of work, aligning it with evil and, therefore, declaring it to be the preserve of those of low spiritual inclinations.

The consequences of this on those who indulged in secular work or those who worked only to eat was that they began to rationalize that since their work was unspiritual or at least less important to God, it did not matter to God how this work was done. Secular work should be done in a secular manner whilst spiritual work should be done in spiritual style. The dichotomy between God and Caesar was thus established. Behaviour in the workplace could be styled after Caesar whilst that in the Church should be styled after God's standards. Gospel ministers became clergy whilst non-ministers became the laity. One now understands why up till now, most Christians carry two identities; one for the secular workplace and the other for the Church. In the Church they are saints, whilst in the workplace they are devils! It should be pointed out here that this 
is a great mistake of the Church, initiated in Middle Ages and perpetrated today. This is contrary to the biblical perspective of work. The late Catholic Pontiff, Pope John Paul VI, laments this development in the contemporary Church and calls for the correction of this position thus:

The split between the faith which many profess and their daily lives is to be counted among the more serious errors of our age ... Let there be no false opposition between professional and social activities on the one hand, and religious life on the other. The Christian who neglects his temporal duties, neglects his duties toward his neighbour and even God, which jeopardizes his eternal salvation.

(Second Vatican Council, Gaudium et Spes)

The Church should, therefore, return to the biblical view of work.

\section{THE BIBLICAL ETHICS OF WORK}

Having established what the biblical perspective of work is, it follows naturally that we proceed to discuss the biblical ethics of work. Our thesis, here, is that if work was originated by God and if it is holy as argued in this article, then, there must be a Godway of approaching work. This embraces both the employee and the employer. On the one hand, we would be raising questions that affect the employee; what are God's expectations from employees over their conduct in the workplace? On the other hand, we would be examining what the Bible expects from the employer of labour or the manager; how are managers to relate to the employees working under them; what kind of wages is the employer expected to pay; when should the wages be paid and under what conditions should the employees be placed? The answers of the Bible to these questions constitute what we refer to as the biblical ethics of work, a term by which we mean the biblical moral principles about work.

Let us begin by acknowledging that in New Testament times, that is, the period covering the writing of the New Testament, employers and employees in the modern sense of the terms did not exist. The nearest parallel to the concept of 'employee' in the

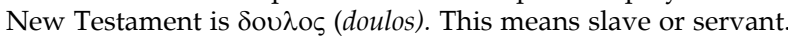
Similarly, the nearest parallel to the concept of 'employer' is кupıs (kurios), meaning 'slave-owner' or 'master' (Guthrie 1981:941). It must also be pointed out that slavery amongst the Hebrews and other Near Eastern peoples was different from slavery as conceived today. People became slaves either as prisoners of war or because of economic debt (Mounce 2006:633). A slave had many privileges which included having a family of his own under his master (if male), owning personal property and under certain circumstances serving even as their masters' heirs (see Gn 15:1-6 \& 24:1-3). Slaves and the modern-day employees differ in that the former had no rights over their lives, whilst the latter are voluntary servants who could withdraw at will from their jobs to take up other more lucrative ones. That notwithstanding the comments of the Bible, about how slaves or servants approached their work and the behaviour of the master to the slave, have much to teach us about work ethics.

In the first place, the Scriptures teach us that all work is Godcentered. As highlighted earlier, we are working on the earth today because at the beginning God commanded all human beings to work (Gn 1:26-28 \& 2:15). This means that ultimately all work that is done on earth is done unto God. This is what Paul had in mind when he wrote the Colossians and said,

Slaves, obey your earthly masters in everything; and do it, not only when their eye is on you to win their favor, but with sincerity of heart and reverence for the Lord. Whatever you do, work at it with all your heart, as working for the Lord, not for men, since you know that you will receive an inheritance from the Lord as a reward. It is the Lord Christ you are serving.

(Colossians 3:22-24, NIV; emphasis added)
Similarly, in his letter to the Ephesians, Paul said,

Slaves, obey your earthly masters with respect and fear, and with sincerity of heart, just as you would obey Christ ... Serve wholeheartedly, as if you were serving the Lord, not men.

(Eph.6:5-7, NIV; emphasis added)

The implication of these two passages is that God is the ultimate Employer of all labour. Thus, Christians are expected to realise that whatever service they render unto men in whatever capacity is service rendered unto God, irrespective of whether the business is owned by a Christian or not. This principle applies to both the employee and the employer or manager. All work is ultimately owned by God. Thus, the employer of labour and the employee are owned by God and are working for Him. If that is the case, how are the employee and the employer expected to do these jobs of theirs for the Lord? Let us first consider the responsibilities of the employee before we go to the employer.

\section{The responsibilities of the employee}

The Bible passages that we have quoted establish certain principles for the employee.

Firstly, the principle of discipline in the workplace entails that the employee is commanded to obey his superior or master. This is to be done with respect, fear and sincerity of heart. The passage clearly warns against eye-service. Similarly, the obedience required is to be given not to win favor of any kind, be it promotion or anything else. The reason why believers are to obey their master is because they are working for the Lord. That means that the Lord is the ultimate Employer. However, the phrase 'in everything' ( $\mathrm{Col} \mathrm{3:22)}$ needs to be qualified. It is assumed that the master would not ask the employee to do anything that is morally wrong, since the master is also working for the Lord. However, if the master or employer begins to make demands that are contrary to the Lord's will, the employee would certainly be expected to obey God rather than men (Ac 5:27-29). Apart from this exception, employees are expected to show decorum and not to be unruly in their relationship with their boss.

Secondly, the employee is expected to be hardworking, diligent and conscientious. In Colossians 3:23, employees are told that whatever they do, they must work at it with all their heart, as if they are working for the Lord. Working with all one's entire heart results in being enthusiastic about one's work; it also means spending one's energy on the job. This applies to issues like resuming for work on time, staying at one's duty post and doing the job for which one is employed without grudges or complaints. It could also mean carrying out one's assignment promptly and not allowing other things to waste the time, which should be spent on the job. The requirement of the Bible over this is that, employees are expected to do their work very well without requiring supervision; this is because of the consciousness that the Ultimate Employer is watching, even if no human supervisor is around (see $\operatorname{Pr} 6: 6-11$ ). The most crucial thing about this is that, in the end, God is going to reward all workers for the way they did their jobs whilst on earth (Col 3:24).

Lastly, employees are expected to be honest and sincere (Eph 6:5 \& Col 3:22). Honesty is the quality of being truthful or faithful. Employees are to be honest or sincere in relation to their employer as well as to the consumers of their labour. This fact rules out all kinds of fraudulent activities such as stealing, misappropriation of funds or resources, bribery and corruption. It also rules out the use of substandard materials for construction or production of goods. The issue also addresses the need to offer quality services wherever such is required from the employee and that without any supervision. 


\section{The responsibilities of the employer}

After Paul finished dealing with the responsibilities of the employees in these passages, he turned to the employer or master. In Ephesians 6:9, Paul writes,

And masters, treat your slaves in the same way. Do not threaten them, since you know that he who is both their Master and yours is in heaven, and there is no favoritism with him.

Similarly, in Colossians 4:1, Paul writes,

Masters, provide your slaves with what is right and fair, because you know that you also have a Master in heaven.

These passages raise very crucial issues that border on the relationship of masters or employers to their servants or employees and the questions of emoluments and conditions of service.

The importance of showing respect and sincerity to employees is seen in verse 5 of Ephesians 6, wherein Paul told employees to respect, fear and obey their masters or employers in sincerity. Now, in verse 9 he says masters or employers should treat their employees or servants in the same way. What he is referring to here is that in the same manner that the employees respect employers, the latter are also to respect the employees. They are not told to obey their employees but to be sincere to them and to treat them as servants of the Ultimate Master. Employers are not to be cruel to their employees (Izibili 2005:357). They are not to harass them, either sexually or emotionally. They are, therefore, told to stop threatening their employees or those who work under them. The reason given for this directive is that both the employer and the employee have God as their Master and that in the end, all of them would give an account to the Master who would judge each of them on the basis of their conduct to either their masters or employees. The critical point is that this Ultimate Master judges without partiality or favoritism. Thus, everyone would receive their due reward.

The instruction to respect their employees includes the issue of abuse or misuse of the employees. Masters are not to take undue advantage of their employees or those working under them. They are not to overwork them but remember that they are also human beings made in the image and likeness of God (see Is 58:3). Employees are to be seen as people of dignity and as not sub-human beings to be exploited by masters or employers.

In terms of employee emoluments employers or masters are instructed in Colossians 4:1 to pay just and fair wages to their employees. This means that the employee is not to be cheated or exploited by the employer or master. Rayburn opines that just wages are wages that are capable of making life comfortable for the worker and wages that are commensurate with the work being done. This does not have to be what is bearable in the market. The wages should be such that make the employee feel happy and satisfied. Elsewhere in the Bible, it is said that the labourer or worker deserves his wages and he is not to be muzzled (Lv 25:43, 53; Dt 24:14-15; Lk 10:7 \& I Tm 5:18); this means that the wages of workers are their right and must be given to them, (Ml 3:5). Not only must the wages be fair, just and paid, they should be paid when due. The situation in Nigeria at present (just as in many other African countries) is that poor working conditions prevail. J.K. Ayantayo (2009:67) makes allusions to these poor working conditions, which include poor pay, poor housing, transportation problems, lack of motivation, poverty, lack of supervision and poor enforcement of work ethics. James wrote that withheld wages or delayed wages cry to the Lord against the employers. He therefore states:

Look! The wages you failed to pay the workmen who mowed your fields are crying out against you. The cries of the harvesters have reached the ears of the Lord Almighty.

(James 5:4, NIV)
The employer is to show sincere concern for his employees and should be made visible by making working conditions employee-friendly. There should be welfare packages, healthcare facilities, housing, staff development packages, free flow of information, et cetera. All these benefits boost the morale of the employees and make them to become committed to their jobs. The other issue is that of job security. Employers should not adopt the 'hire and fire' attitude; this is because insecurity of jobs contributes to indiscipline and infidelity on the part of employees.

The employer is also expected to be honest, fair and just to customers, that is, those who benefit from the services provided by the employers' organizations. In Deuteronomy 25:13-16 it is written:

Do not have two differing weights in your bag - one heavy, one light. Do not have two differing measures in your house - one large, one small. You must have accurate and honest weights and measures, so that you may live long in the land the Lord your God is giving you. For the Lord your God detests anyone who does these things, anyone who deals dishonestly.

(Deuteronomy 25:13-16, NIV)

The employer is not to cheat anyone. In the context under consideration, the measures and weights had to do with those who sold grain or other materials to others. To use a small measure or wrong weight for the unsuspecting customer was to invite God's wrath and to beg for premature death as shown in the passage quoted from the book of James.

Those who provide any kind of service must therefore ensure that the right amount of materials required for the production of articles or the construction of roads or buildings are used. The foregoing, therefore, are the general ethical principles surrounding the conduct of work of any kind. These principles can apply to work of any kind and to workers of various degrees, both in the private and public sectors. We shall now turn specifically to Nigeria to show how these principles could be of benefit to her work force and the continent at large.

\section{NIGERIA AND BIBLICAL WORK ETHICS: A REPRESENTATIVE SAMPLE FOR AFRICA}

The nation of Nigeria got her independence from the British overlords in 1960. This was celebrated with fanfare. The era of exploitation by foreigners had at last come to an end, it was hoped. The same was applicable to many other African countries. Now had come the time for the indigenes to build their fatherland by themselves and to decide how it should be governed.

However, what one has seen over the last forty years or more has made many to wish that the colonial masters had continued to rule over Africa for much longer than they did. For instance, in Nigeria one hears those who lived during the colonial days lament the deplorable conditions in the nation nowadays in comparison with the golden days of the colonial masters. Then, they argue, things were done the way they should be done. The houses, roads, bridges and other building projects executed at that time were done with the best and right proportion of the materials required for them. So also were the consumer goods that were sold in the nation's markets. A good number of such building projects still stand formidably and are still in a very good state whilst many of those that have been executed in the last few years have either collapsed or are in a state of disrepair. Representative of those voices is S.O. Abogunrin (2007) who writes thus:

Corruption has left Africa, almost economically barren with untold hardship, hunger, disease and woes. Most of the public facilities in schools, hospitals, and in public buildings which functioned well about fifty years ago, immediately after independence have become part of the forgotten history of African nations. Hardly 
does anything work anymore in Africa. Well equipped functioning schools and hospitals with drugs and adequate medical personnel and facilities are no longer available. Regular supply of clean water, electricity and good roads, hardly exist. Young people today are not aware that those things, including the phones, once functioned well in many African countries.

(Abogunrin 2007:9)

Similarly, there is a lot of wasteful spending and irresponsibility on the part of both the leaders and the led (Dzurgba 2003:51). Very pertinent examples are the deplorable state of Nigerian roads and the collapse of buildings in major cities like Lagos and Ibadan. Others are the flooding of our markets with counterfeit products such as fake drugs, building materials, automobile spare parts, foot wear and fabrics (Nworah 2006:8)

Also recently, at the 39th Convocation lecture of the University of Nigeria, Nsukka (UNN), the Nigerian Minister of Information, Prof. Dora Nkem Akunyili (2010) had this to say about the deplorable state of infrastructure in the country:

The topic of my lecture, 'Re-branding Nigerian Universities' is apt, because it is coming at a time when all hands are on deck to re-brand every sector of our dear country. When something is to be re-built, it means it has degenerated from its original structure. It is common knowledge that our university system has degenerated to the extent that it needs re-building, resuscitation or indeed Rebranding. In the 1960s, 1970s, and even in the early 1980s, those of us who attended Nigerian institutions of higher learning can attest to those glorious years of our educational system. ... Very sadly, those glorious years are now behind us. Unfortunately, what we have in place today ... are insufficient, overcrowded classroom spaces, and non-existing or dilapidated laboratories.

(Akunyili 2010)

The questions that boggle one's mind is why are we in this type of situation. One wonders why the nation is not making the desired progress. It is also unthinkable that our nation has turned the opportunity to better our world into a curse. One can only hope that someday we would come to the realization that things should be done right and that our religiosity should be used to find concrete solutions to our problems of underdevelopment.

Many scholars have identified different reasons for and causes of retardation in the technological and economic development of Africa. In their study titled 'Did Colonization matter for growth? An empirical exploration into the historical causes of Africa's underdevelopment', G. Bertocchi and F. Canova (2002:1852) attribute the failure to the 20th century European colonization of Africa. They also draw attention in their article to other causes of this problem identified by other scholars such as Easterly and Levine (1997) who attribute the problem to ethnic diversity, Schmidt-Hebbel (1996) who blames it on the role of fiscal policies and Sachs and Warner (1997) who see the impact of geography as the bane of development in Africa. Whilst the findings of the foregoing scholars are valid in their contexts this article argues that, for Nigeria and the rest of Africa to begin to prosper and develop technologically and otherwise we may need to adopt the biblical work ethics model as a major solution. There must be a change of focus and a reorientation of the general workforce in the nation, in particular and in the continent at large. Religious clerics and teachers must take it upon themselves to teach these principles more than ever before. The work ethics should be given the prime place in their teaching and preaching programmes. If this is done faithfully along with other measures there could be some hope for Africa.

It is therefore recommended that both government functionaries and the citizens must apply certain ethical principles.

In the first place, the so-called 'government job' syndrome must be jettisoned. African workers should stop thinking that they are working for government. They should see themselves as working for the Ultimate Master or Employer, that is, God. As such, they should realize that, whatever they do on their jobs is being watched by the Almighty. They should also remember that the Lord would reward them for whatever they do, either good or bad. They should, therefore, see their jobs as a vocation or God's calling. Thus, the usual way of doing government work anyhow, because it is no one's work, or stealing government property in the name of the 'national cake' should stop forthwith, if we must make progress and fulfill the 21st century vision.

Promptness to resume work should be regarded as an important duty of employees. Arising from the preceding ethical principle, employees and students must attend to their work and study schedules promptly and regularly. Efforts must be made to avoid all forms of lateness, whether people are lecturers, administrators, skilled workers or students.

When employees resume their work, they should not merely sign the register of attendance and leave their place of work in the pursuit of their private business or political agenda, as is often the case. Lateness and truancy are tantamount to stealing the employers' time and getting paid for work not done.

Employees should concern themselves with what they are employed to do. They must not only report and remain at their duty post, chatting, sleeping, praying or entertaining themselves or visitors when there is work to be done; they should not wait for inducements such as bribes or sex before they do their jobs.

Employees must not steal government or company property or money, neither should such funds be misappropriated nor kept in private accounts in order to earn interest which goes into employees' private purses. The Ultimate Master detests dishonesty and ill-gotten gains and would punish those who indulge in it.

Employees must exhibit diligence and hard work and must show commitment and enthusiasm in doing their job. Those in positions to execute certain actions must not wait for people to come and see them before they do their work. The practice of follow up before letters or other documents are signed or dispatched should be abolished.

As established in the biblical work ethics, employees are expected to honour and respect their superior. Insubordination in speech or attitude should, therefore, not be harboured. Directives or assignments must be executed promptly. The employee must not wait for a reminder or a follow up before carrying out the required assignment.

The next set of principles concerns the administrators or employers of labour. As stated earlier, the first principle also applies to them (i.e. 'government job' syndrome) which means that they too should see themselves as employees of the Ultimate Employer, that is, God. They should conceive of themselves as working not just for the Presidents of their countries (or whatever the case may be), but for the Lord. This will give new meaning and a different approach to the way they go about their business. In light of this, they would be expected to apply certain principles in the performance of their duties.

They must allow honesty to be their guiding principle in all that they do to those working under them and the consumers of their products. This should begin with the kind of policies they push forward and the implementation of constitutional provisions of their countries. It should also affect their management of state finances and personnel resources. The recruitment of staff should be based on quality rather than nepotism, gratification and ethnic considerations. In order to ensure that the personnel turned out by our educational institutions are well baked laboratory, technological and library facilities should be updated on a regular basis, as well as other infrastructure facilities.

The administrators should strive to see that health care housing and staff development programmes are put in place 
for employees. These have a way of boosting the morale of staff members with attendant positive consequences on their effective performance. Most of all, the promotion of deserving staff members should be of paramount concern to the administrators. Staff members who remain in one rank for too long feel frustrated and if they cannot find an alternative elsewhere, they begin to shift this frustration to the recipients of their services. They could resort to acts of indiscipline, or begin to reduce their performance on the job. If they are not religious, they may even resort to the consumption of narcotic drugs, alcoholism or cultism. In the light of this, it would be in the interest of the administrators and the entire populace to reward hard work appropriately. Besides, the administrators should make the working environment of staff attractive and conducive. Employees who work in a wellfurnished and clean environment feel proud about their job and become attached to it with a corresponding output. This also makes them feel important in society.

As pointed out in the section on biblical ethics of work, employers are told to pay their employees fair and just wages. It is common knowledge now that many sound lecturers and other skilled staff of African nations are on the run for greener pasture in Saudi Arabia, Europe and the United States of America. This trend, known as brain drain, is doing a lot of havoc to the developmental efforts of African nations. To arrest this trend, the nations must pay just and fair wages. This means that the wages must be positively comparable to those in these countries where our best brains are being enslaved. This should affect not only those in active service, but also those who retire after meritorious service to their nations. Such measures would make people settle down in the continent and work to improve our continent.

Employers should place value on staff members and not on things and should note that human beings are more important than silver and gold. People, from the point of view of the Bible, are more valuable than the world and its resources put together. When therefore the life of a staff member is in danger, nothing should be spared to help save such a life. Similarly, schemes that help to develop the families of staff members should be encouraged.

\section{CONCLUSION}

The desire and effort of many African governments to build world-class economies and technologies in the 21st century is quite laudable. However, laudable as it is, it would be mere daydreaming if a corresponding action is not matched with the desire. This article has argued that one good way of bringing about this desired change is first to change the orientation of the workers of the African nations about work. It means to adopt a new ethics of work, which is none other than the biblical work ethics. If the biblical work ethics is adopted and adhered to strictly by every stakeholder in Africa, the whole world would soon start singing a new song about the African continent. The problem created by this recommendation is that not all Africans or Nigerians are Bible believers. How then could the biblical ethics apply to them? For such as are not Bible believers, these principles do not have to be religious principles or Christian principles. What may be necessary may just be to extract these principles and call them attitudinal work ethics so that they can be generally acceptable. In the case of Nigeria where about $90 \%$ of the people are religious adherents it may do no harm in calling these principles 'religious principles'. If this becomes acceptable it would be a significant contribution in search of a developmental solution in Nigeria and the whole of Africa.

\section{REFERENCES}

Abogunrin, S.O., 2007, 'General Editor's Introduction', in S.O. Abogunrin, J.O. Akao, D.O. Akintunde, K. Dada, G.N. Toryough \& P.A. Oguntoye (eds.), Biblical Studies and Corruption in Africa', Biblical Studies Series, No. 6, pp. 8-11, Nigerian Association for Biblical Studies, Ibadan.
Akunyili D.N., 2010, 'Re-branding of Nigerian Universities', paper presented at the 39th Convocation Lecture of the University of Nigeria, Nsukka, 05 August, viewed 07 September 2010, from http://www.unn.edu.ng/images/ convocationk_convocation_lecture.pdf

Aluko, M.A.O., 2004, 'Social-cultural Dimensions of Motivation and Management in Nigeria', AJPAM, XV(1), 37-53, viewed 09 October 2009, from http://unpan1.un.org/intradoc/ groups/public/d

Amadi, E., 1982, Ethics in Nigerian Culture, Heinemann Educational Publishers, Ibadan.

Ameson, R.I., 1997, 'Meaningfulness of Work and Socialization', Ethics 97(3), 517-545.

Ayantayo, J.K., 2009, 'Oath-taking and Governance in Nigeria', in I.O. Albert (ed.), Praxis of Political Concepts and Cliches in Nigeria's Fourth Republic, Essays in Honour of Dr Mu'azu Babangida Aliyu, Bookcraft, Ibadan, p. 57-73.

Balstore, E., 1988, The Reform of Work Place and Industrial Relation: Theory, Myths and Evidence, Clarendon Press, Oxford.

Barker K.L. \& Kohlenberger J.R. III, 1994, The Expositor's Bible Commentary, O.T., abridged edn., pp. 7-8, Zondervan, Grand Rapids.

Belcher, D.W., 1962, Wage and Administration, Prentice Hall, Englewood.

Bertocchi, G. \& Canova F., 2002, 'Did Colonization matter for growth? An empirical exploration into the historical causes of Africa's underdevelopment', European Economic Review 46, 1851-1871, viewed 07 September 2010, from www.elsevier. com/locate/econbase

Boer, H., 1976, A Short History of the Early Church, Daystar, Ibadan.

Clarke, P., 1991., 'Religion and Political Attitude since Independence', in Olupona J.K. \& Falola T. (eds), Religion and Society in Nigeria:Historical and sociological Perspectives, pp. 216-229, Spectrum Books Ltd, Ibadan.

Davis, H.H., 1988, 'Work', in SB. Ferguson, Wright DF. \& Packer JI.,(eds), New Bible Dictionary of Theology, p. 728, Universities and Colleges Christian Fellowship, Leicester.

Dzurgba, A., 2003, Nigerian Politics and Moral Behaviour, A Study in Politics and Moral Behaviour, John Archers, Ibadan.

Dzurgba, A., 2007, Contemporary Ethics: Theory and Issues, John Archers, Ibadan.

Demonstratio Evangelica, I, viii, in W.R. Forester, Christian Vocation, 43, Rayburn 2006.

Erondu, E.A., Sharland, A. \& Okpara J.O., 2004, 'Corporate Ethics in Nigeria: a Test of the Concept of an ethical Climate', Journal of Business Ethics 51(4), 349-357.

Falola, T. \& Babalola D., 1991, 'Religion and Economy in Precolonial Nigeria', in Olupona J.K. \& Falola T. (eds), Religion and Society: Historical and sociological Perspectives, pp. 151-169, Spectrum Books Ltd, Ibadan.

Grint, K., 1991, The Sociology of Work: an Introduction, Polity Press, Cambridge.

Guthrie, D., 1981, New Testament Theology, Intervarsity Press, Leicester.

Hargreaves, J., 1998, A Guide to Genesis, New edition, SPCK International Study Guide no. 3, Society for Promoting Christian Knowledge, London.

Harmon, M., 2007, Labor Day Reflections on Work, viewed 09 July 2009, from http://bibtheo.blogspot.com/2007/09/labor-dayreflections-on-work.html

Izibili, M.A., 2005, 'The Responsibilities of Business Organizations: An Ethical Insight', in P.O. Iroegbu \& A.O. Echekwube (eds.), Kpim of Morality Ethics, General, Special and Professional, pp. 356-361, Heinemann Educational Books (Nigeria) PLC, Ibadan.

Jeremias, n.d., Rediscovering the Parables, in Ryken, Worldly Saints, 24, cited by Rayburn 2006, viewed 07 July 2007 from http:// www.faithacoma.org/series/work.aspx. 
Kuiper, B.K., 1964, The Church in History, Wm. B. Erdmann's Publishing Company, Grand Rapids.

Lawuyi, T., 1991., 'Nigeria in the 1980s: Religion and National Integration', in J.K. Olupona \& T. Falola (eds), Religion and Society in Nigeria: Historical and sociological Perspectives, p. 230-243, Spectrum Books Ltd., Ibadan.

McDonald, H.D., 1982, 'Work' in J.D. Douglas, Hillyer, N., Bruce, FF., Guthrie, D., Millard, AR., Packer, JI \& Wiseman, DJ., (eds.), New Bible Dictionary, 2nd edn., pp. 1260, Intervarsity Press \& Universities and Colleges Christian Fellowship, Leicester.

Mounce, W.D., Smith D.M. \& Van Pelt, M.V. (eds.) 2006, Mounce's Complete Expository Dictionary of Old and New Testament Words, pp. 632-635, Zondervan, Grand Rapids.

Natural Theology Synopsis, n.d., Work, viewed 15 October 2007, from www.naturaltheology.net

Nworah U., 2006, 'Rebranding Nigeria; Critical Perspectives on the Heart of Africa Image Project', viewed 07 September 2010, from http://www.brandchannel.com/images/ papers $/ 4$

Olugbile, F., 1997, Nigerian Work: A Survey of the Psychology of Work among Nigerians, Malt House Press Ltd, Lagos.

Oparanma, A.O., 2008, 'Motivation and Productivity: Study of civil Servants in Rivers State, Nigeria', Research Journal of International Studies 7, 43-55.
Polano H., 1973, The Talmud; Selections from its commentaries, teachings, poetry, and legends, transl. by H. Polano , Frederick Warne \& Co. Ltd., London/New York.

Pope Paul VI, 1965, 'Pastoral Constitution on the Church in the Modern World', Gaudium et Spes IV(43), viewed 08 June 2008, from http://www.vatican.va/archive/hist_councils/ ii_vatican_council/documents/vat-ii_cons_19651207_ gaudium-et-spes_en.html

Rayburn, R.S., 2006, 'Theology of Work' Sermon Series, viewed 07 July 2007, from http://www.faithacoma.org/series/work. aspx

Sowumi, B., 2004, 'The Role of Labour in National Development', The Constitution 4(3), 18-34.

Uka, F., 2010, 'Ebonyi Gathering for Attitudinal Change (1) [ANALYSIS]', 16 Jul. 2010 viewed 14 Aug. 2010, from http:// allafrica.com/stories/201007160242.htm

Vine, W.E., Unger, M.F. \& White, W., 1996, 'To Work' and 'Work', Vine's Complete Expository Dictionary of Old and New Testament Words with topical Index, pp. 293 \& 683, Thomas Nelson Publishers, Nashville.

Vroom, V.H., 1964, Work and Motivation, Wiley, New York.

Yousef, D.A., 2001, 'Islamic Work Ethic: a Moderator between organizational Commitment and job Satisfaction in a cross-cultural Context', Personnel Review 30(2), 152-169. 